\title{
RESPONSE OF BIRDS TO AN ECLIPSE OF THE SUN
}

\section{JOHN P. MORGAN, P.O. Box 776, Dauphin, Manitoba. R7N 3B3}

A sweeping black curtain engulfed the prairie in inky darkness. The horizon was an icy turquoise pallisade guarding against invasion by the sun's fire. Gusty mid-winter winds rattled snow crystals across somber fields, then ceased. The silence was demanding, overpowering. A world waited, hushed and awed, for daylight to return.

The scene was not one imagined in a science-fiction thriller or artificially created on a movie set. It was a frosty Manitoba morning, 26 February 1979: the day of the total solar eclipse, one which few will ever forget.

The eclipse, in addition to being a memorable event from a human viewpoint, was equally important to various species of overwintering birds. This most unusual natural phenomenon provided a unique opportunity to study bird behaviour. Rapidly changing light levels provided by the eclipse furnished a ready-made experiment to test the effects of photoperiod on avian activities under natural conditions.

Reports of bird behaviour were solicited throughout the eclipse path in Manitoba by ads placed in local and regional newspapers, posters, a C.B.C. radio interview and personal contact. $A$ total of 54 people responded to the survey. The geographical area covered by observers was from Regina, Saskatchewan to Vermillion Bay, Ontario and Pilot Mound to Hodgson, Manitoba. Habitat types ranged from downtown urban, suburban yards to prairie, aspen parkland and boreal forest. Most observations were made at bird feeders.

Temperatures at eclipse time (1046 C.S.T.) were $-11^{\circ} \mathrm{C}$ in Winnipeg, $-13^{\circ} \mathrm{C}$ in Brandon and $-18^{\circ} \mathrm{C}$ in
Dauphin (Atmospheric Environment Service, personal communication). Winds were light ( 13 to $19 \mathrm{~km} / \mathrm{h}$ ) and all three stations reported a thin overcast of cirrus clouds. The eclipse did not result in any significant changes in weather patterns in those locales.

The 54 respondents provided 105 separate observations on 25 bird species. They provided a representative cross section of the winter birds normally present in Manitoba.

\section{SHARP-TAILED GROUSE}

Two reports of Sharp-tails were received, both from rural areas. At Fraserwood, a flock of 15 flew in from east of the observer. They landed on top of a row of hay bales two minutes before totality. The birds were very active and nervous, clucking continually throughout the eclipse. Immediately after the sun reappeared the grouse flew south towards a woodlot. Two grouse feeding in a Headingly back yard became very alert as the darkness increased. They walked part way up a one meter high earth mound and flew away just after totality.

\section{ROCK DOVE}

Six observations of Rock Doves (more commonly known as domestic pigeons) were reported. In Pilot Mound, St. Laurent, and downtown Winnipeg, totality caught three flocks of doves in flight. They exhibited erratic flight patterns apparently becoming confused and disoriented. Doves were also seen to roost on buildings, beginning five to ten minutes before totality till up to 12 minutes after. They showed typical roosting behaviour: huddling together 
with bills tucked in their scapular feathers. A third type of behaviour was demonstrated by still other urban Rock Doves. These birds continued flying normally throughout the eclipse, displaying no obvious reaction to it.

\section{MOURNING DOVES}

Two Mourning Doves overwintering in Carman became very active just before totality, then went to roost on a rooftop, remaining motionless until sunlight returned. At this time they began to hop around and finally flew off.

\section{GREAT HORNED OWL}

A tamarack bog near Hodgson revealed two owls that began hooting four minutes before totality and continued until one minute before totality. One bird hooted three times, the other two. The owls were approximately 200 meters apart. In the Spruce Woods and at Lac du Bonnett, single Great Horned Owls were heard calling during and after totality.

\section{SNOWY OWL}

A lone Snowy Owl was observed by several people in the industrial area of northwestern Winnipeg coming to feed on a dead White-tailed Jackrabbit during totality. The rabbit was thought to be the owl's own kill. As the sun returned, the Snowy Owl stopped feeding and flew off.

\section{GREAT GRAY OWL}

Five observers in the Lac du Bonnett area reported on the behaviour of 20 Great Gray Owls seen the morning of the eclipse. One flew out from its perch three times in large circles prior to totality. During the eclipse, it sat still on top of a telephone pole. Most of the other owls were seen on high perches. The most noteworthy aspect of the observations was that it was very unusual to see that many owls out during an otherwise bright (except for the eclipse) winter day.

\section{RED-HEADED WOODPECKER}

This species was recorded at two feeders in southern Manitoba. Both individuals exhibited behaviours normally associated with dusk and dawn. They flew off to roost a few minutes before totality, then returned to their feeders as daylight increased.

\section{HAIRY WOODPECKER}

A Hairy Woodpecker stayed at a feeder in Baldur until seconds before totality, returning quickly after the sun reappeared.

\section{DOWNY WOODPECKER}

This smallest resident woodpecker was seen to react similarly to the Redheaded Woodpeckers at two feeders. A third Downy, however, remained at an Anola feeder throughout the eclipse. It did not interrupt normal feeding activities, apparently oblivious to the lighting conditions.

\section{BLUE JAY}

Eight accounts of Blue Jays were received from widely scattered areas of the province. Four noted the typical nightfall roosting and daybreak return to feeding behaviours seen in other species. In Cypress River, this pattern also was followed with the exception that upon coming back to the feeder, the jays vocalized on a window sill rather than their usual treetop perches. Blue Jays in Stonewall left their feeder as it became dark. They "screamed" loudly throughout totality, returning about ten minutes later. Seven jays in Pinawa flew west from a feeder to a nearby wooded area two minutes before totality. When observations ceased one half hour later, they still had not reappeared. A lone Blue Jay at a Brandon feeder remained throughout the eclipse, even though a flock of House Sparrows left the same feeder as it darkened.

GRAY JAY

Four Gray Jays at a feeder near 
Wallace Lake exhibited noticeably greater than normal activity in the 35 minutes preceding the eclipse. All left the feeder by eight minutes before totality and were silent. The only exception was a single whistle heard four minutes before totality. Normal activities about the feeder resumed approximately 11 minutes after the sun reappeared.

\section{BLACK-BILLED MAGPIE}

A single magpie at a feeder in Amaranth was observed to feed amicably with several Black-capped Chickadees, Blue Jays and woodpeckers. This was noteworthy as the different species did not usually tolerate each others' presence and normally fed at different times. The morning of the eclipse, however, they all arrived at the same time. No inter-specific aggression was seen. The birds "ate as though it was their last meal". All departed before totality with only the Chickadees returning later that afternoon.

\section{COMMON RAVEN}

Five ravens flying north over a runway at the Winnipeg airport dipped sharply down and to the east (as if they had been physically hit) when the shadow of the eclipse passed them. They then continued flying north, but at a lower altitude than previously. One raven perched on a dead spruce tree in a tamarack bog near Hodgson for at least 30 minutes before totality then 45 minutes afterwards until observations ceased. It had no apparent reaction to the eclipse, although its behaviour was not observable during the darkest part of totality.

\section{COMMON CROW}

One crow was noted flying east to west over downtown Winnipeg, cawing, just prior to totality.

\section{BLACK-CAPPED CHICKADEE}

A total of 11 accounts of this species was received. Seven indicated Chickadees at feeders left the area as

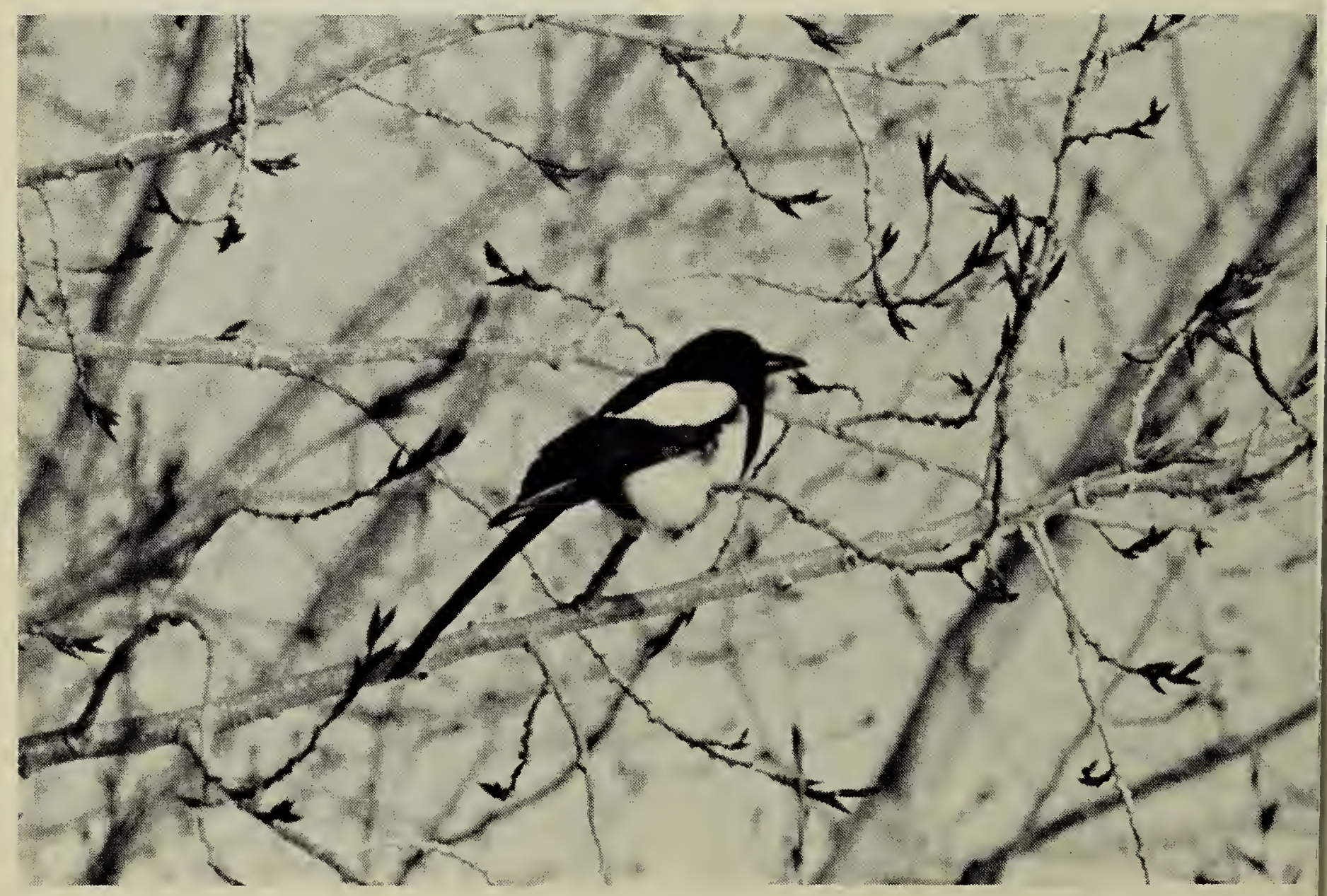


returning to feeders as light levels increased once again.

\section{HOUSE SPARROW}

This familiar resident was reported from 15 locales throughout the province. Nearly all (14) observations were of flocks flying off to roost as the sun's light waned, returning to normal activities fairly quickly after the eclipse. Two flocks went to multicelled Purple Martin houses, which are customary nighttime roosts for House Sparrows in winter. Others roosted in evergreen trees, which are also usual nighttime roosts. Several observers noted a significant increase in vocalizations just before and after totality. This phenomenon is usually shown by sparrows at dawn and dusk. One group was heard to give alarm calls as the light decreased. In Stonewall, a female House Sparrow was recorded flying frantically south to north (as if being pursued) during totality to a spruce tree. Here it quickly settled down to roost. Sparrows in St. Eustache were observed flying erratically and hitting a building during totality.

\section{EVENING GROSBEAK}

Eight reports of Evening Grosbeaks were received. Seven feeders had grosbeaks leaving to roost during the pre-eclipse darkening and returning at varying times after totality. Generally, this species appeared to leave earlier and return later than other birds. One observer noted the grosbeaks beginning to get quite lazy at three quarters totality, but still feeding for a few minutes before flying off to roost. In Kelwood, a flock flew around erratically before totality, finally settling down to roost in a spruce tree. They were more vocal afterwards, and fed voraciously. Forty to 50 from a Pinawa feeder flocked together and headed southeast to a clump of spruce and balsam fir approximately two minutes before totality. Large flocks came from all directions to this clump, apparently using it as a communal roost during the eclipse. When observations ceased one half hour later, no grosbeaks had returned to the original feeder.

\section{PINE GROSBEAK}

One report of several Pine Grosbeaks at a feeder had the birds flying off to roost as totality approached. They then returned to feed as light levels became more normal.

\section{REDPOLL SPECIES}

This species was recorded at six locales on eclipse day. In four areas, redpolls at feeders left to roost as light levels began to decrease noticeably. They resumed normal activities fairly rapidly after totality. In Pinawa, six redpolls flew off from a feeder to roost in a clump of spruce, fir, birch and willow 20 $m$ away two minutes before totality. When observations ceased one half hour later, none had yet returned to feed. A flock estimated to be between five and ten individuals in an interlake tamarack bog began singing two minutes after totality. They continued singing for ten minutes. The calls sounded identical to those given by redpolls in the early morning after sunrise. Observers had been in the area 30 minutes before the eclipse, but did not hear or see any redpolls until after the sun returned.

\section{PINE SISKIN}

A lone Pine Siskin at a rural feeder was recorded flying off to roost with several other species before the eclipse. It then returned with them to feed as the light became brighter.

\section{DARK-EYED JUNCO}

Two juncos overwintering at a downtown Winnipeg feeder reacted similarly to other birds: departing to roost as totality approached, coming back to the feeder as light levels returned to normal. 
SNOW BUNTING

This common winter resident was recorded twice on eclipse day. At one rural feeder, a Snow Bunting flew off to roost before totality and returned afterwards. A flock of 25 was observed in a field near Fraserwood. They landed just south of a row of hay bales before totality, chirping and hopping around, making an unusual amount of noise. After roughly two minutes, the flock got up and circled the field, apparently restless. No activity was recorded during the eclipse. Afterwards, they were seen flying around the field again, vocalizing frequently.

\section{Discussion}

The 105 observations of various species provided some interesting insights into some of the mechanisms of avian behaviour. By far the most common reaction exhibited by the greatest number of birds (18 species/53 observations) was roosting during totality and for varying periods before and after it. This comes as little surprise as the direct influence of photo-period on birds has been well documented. Changes in light levels throughout the day are known to affect singing, feeding, and activity rates. ${ }^{4}$ Approaching darkness in the evening generally stimulates roosting behaviour in diurnal species. Similarly, increasing light levels in the morning signals the return to normal activities.

The bulk of the birds observed on eclipse day reacted just as they would have to nightfall and dawn. Roosting began up to 12 minutes before totality and lasted for varying lengths of time afterwards. Although the eclipse occurred less than three hours after sunrise, most birds seemed to accept it as signalling the end of a very brief "day" and prepared to roost. The rapid return to daylight a short time later brought most back to whatever they had been doing beforehand.
Several observers reported the departure before totality and subsequent arrival of birds after the eclipse followed the normal daily schedule shown by various species at feeders. As anyone who has ever watched a feeder closely knows, different species generally arrive and depart at certain times of the morning and evening. The timing of a given species is often so predictable that one can set his watch by their comings and goings. It is significant to note that a highly unusual event such as an eclipse did not alter the usual patterns of when feeding ended and began.

A striking example of response to the eclipse by a nocturnal species, the Great Horned Owl, also reflects the important role light regime plays in regulating bird behaviour. While most other birds were going off to roost as the eclipse approached, four owls began hooting. These calls are normally given at dusk, or on days with heavy overcast. As in the diurnal species that went off to roost, the owls were "fooled" into believing night was descending.

Another species of owl, the Great Gray, appeared to react to the lower light levels of both the partial and total phases of the eclipse. This species is most often observed on bright days at dawn and dusk, and when the sky is overcast. ${ }^{3}$ On the morning of 26 February, an unusually large number of Great Gray Owls (20) was observed for a sunny day. Their increased activity was seemingly due to the lower than normal light levels provided before, during, and after the eclipse. It appeared they were demonstrating an instinctive reaction to the change in photoperiod.

Not all birds, however, demonstrated a simple instinctive reaction to the changing light levels of the eclipse. Ten species were recorded as obviously reacting to the eclipse. Two (Rock Dove and House Sparrow) became dis- 
orientea in flight. Eight species responded with behaviours ranging from general nervousness and increased vocalizations (Sharp-tailed Grouse, Blue Jay, Common Crow, Whitebreasted Nuthatch, House Sparrow, and Snow Bunting), to peculiar flight patterns (Common Raven) and conspicuous absence from a feeder (Blackcapped Chickadee). These birds evidently sensed something was amiss and did not simply go to roost.

One plausible explanation for these behaviours is the internal conflict between the urge to roost with approaching darkness and the endogenous 24 hour "clock" which regulates some avian behaviours. ${ }^{4}$ The peculiar eclipse situation which created nearly total darkness during midmorning could have stimulated the two opposing instincts, resulting in seemingly incongruous displacement activities. More detailed information would be necessary, however, to demonstrate conclusively that this did occur during the 1979 eclipse.

Six species were observed to totally ignore the eclipse phenomenon. One observation each of Rock Dove, Downy Woodpecker, Blue Jay, Common Raven, Black-capped Chickadee and White-breasted Nuthatch documented individuals continuing normal activities as if nothing extraordinary was taking place. These birds apparently relied upon their internal clocks to tell them that it would not be nighttime yet, and continued, unmoved, on their daily tasks.

A study of the 20 July 1963 total solar eclipse in Saskatchewan found singing rates increased markedly before and after totality. There was almost a complete absence of activity during the time the sun disappeared. ${ }^{2}$ Resumption of normal behaviours was gradual and varied from species to species. Cliff Swallows showed increased feeding activities after the eclipse.
Results from the present study also show increased vocalizations of many species in response to the varying light levels. The birds in both cases were apparently demonstrating the instinctive drive to sing under conditions that approximated dusk and dawn. The increase in feeding rate shown by Cliff Swallows in Saskatchewan similarly was demonstrated by a flock of Evening Grosbeaks at a Kelwood feeder in the 1979 eclipse. Reasons for this intensive feeding behaviour are unclear, but it may reflect the uncertainty brought about by this highly irregular event.

Since a total solar eclipse happens relatively infrequently and lasts for only a few minutes at a given location, natural selection would not be expected to provide instinctive mechanisms to cope with it. Birds are left to their own devices to deal with the situation. The resulting intra and interspecific variation in response shows the confusion which can result from circumstances that do not fit normal daily or seasonal routines.

This variation was also noted by Elliot and Elliot who studied singing rates of warblers and sparrows during the 10 July 1972 total solar eclipse in Nova Scotia." Species there mainly responded to the external control of light levels and demonstrated behaviours characteristic of dusk and dawn. Some, however, exhibited an internal control over song rates, suggesting the 24 hour clock or circadian rhythm was responsible for triggering behaviours. Although the two earlier studies are not directly comparable to the present one due to different methods and the times of year involved, it is significant to note that similar results were found and conclusions reached.

Additional research is evidently necesssary to more clearly define the role that light regimes and internal rhythms play in avian behaviour. This study indicated the importance of both in birds' lives. Just as importantly, it 
showed the contribution that can be made by people from all walks of life to basic science.

\section{Acknowledgements:}

Special thanks to Dan Soprovich for assistance in collecting the eclipse bird observations and R.W. Nero for invaluable comments on the manuscript. Also my sincere gratitude to the many people who contributed their observations to this study: M.Z. Bernstein, B. Brereton, B. Burdeyny, R. Bryant, J. Cairns, J. Chaboyer, M. Cluff, N. Cooney, H.W.R. Copland, T.P. Copps, W. Cowan, M. Crawford, C. Cuthbert, E. Dowie, J.E. Dubois, B. Ethier, D. Evans, D. Fast, K. Gardner, R.C. Goulden, R. Hall, J. Hewett, J. Jefkins, K. Johnson, K. Kemp, H.L. McMillan, L. McMillen,
M. Mollard, W. Mosterd, N. Murdoch, D. Nairne, I. Nelson, J. Pask, E. Perry, J. Porter, M. Richmond, H.P. Rose, D. Russell, M. Schrader, G. Sinclair, R.R. Smith, G. Sutherland, R.R. Taylor, H. Thorvaldson, R. Tuokko, D. Webb, H. Wheeler, J. Wilson, R.E. Wrigley and B. Zielinski.

'ELLIOTT, J.A. and G.H. ELLIOT. 1974. Observations on Bird Singing During a Solar Eclipse. Canadian Field Naturalist 88: 213-217.

${ }^{2} \mathrm{FOX}$, G.A. 1966. Observations of the Effect of a Solar Eclipse on Bird Activities. Blue Jay 24: 87-88.

${ }^{3}$ NERO, R.W. 1980. The Great Gray Owl Phantom of the Northern Forest. Smithsonian Institution, Washington.

${ }^{4}$ WELTY, J.C. 1975. The Life of Birds. W.B. Saunders Company, Philadelphia.

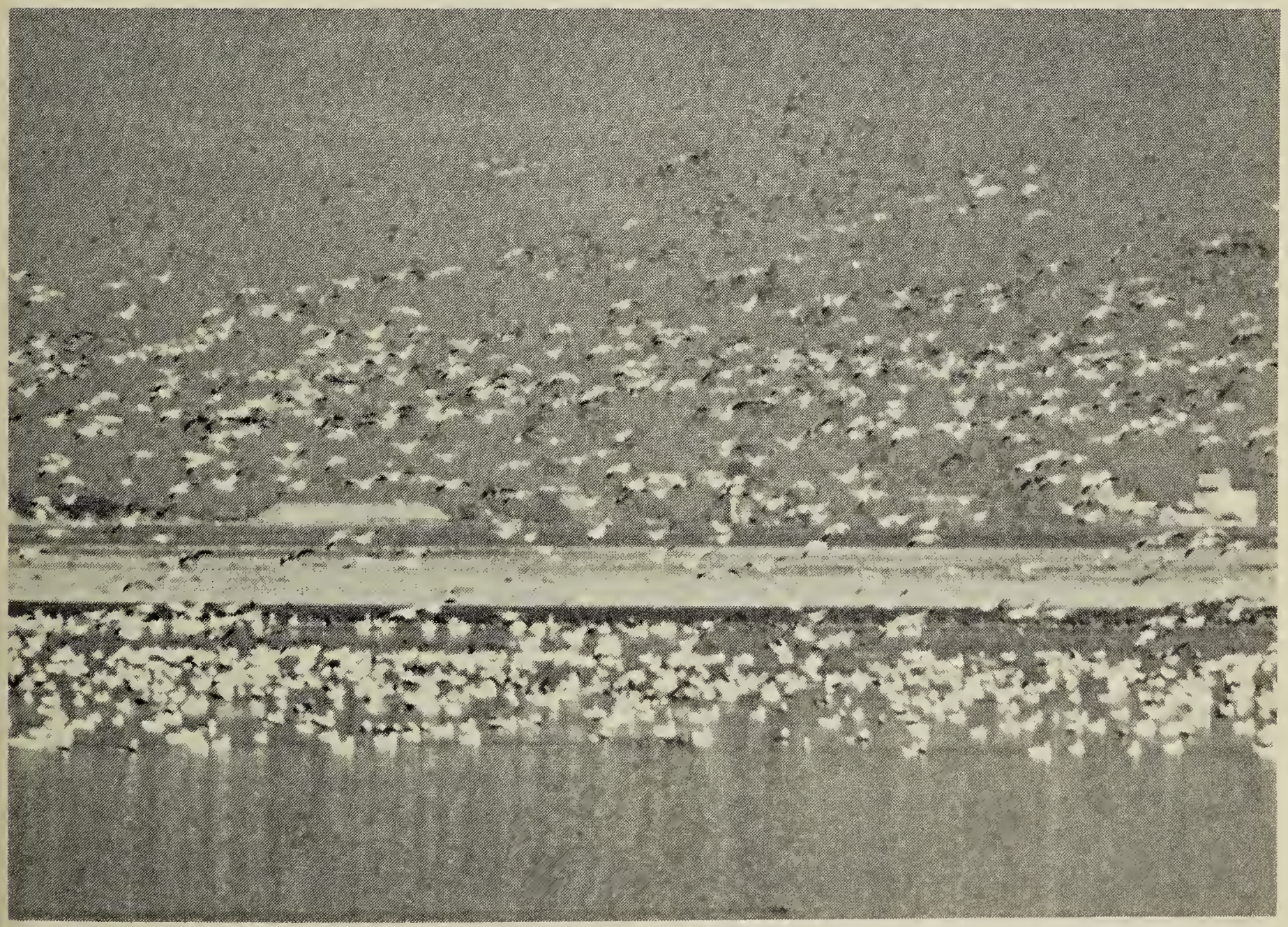

